\title{
Optimal model for additional operation of the storage system for photovoltaic wind power plants
}

\author{
E.B. Saitov ${ }^{1, *}$ \\ ${ }^{1}$ Tashkent State Technical University, Uzbekistan, 100095, Tashkent, University St., 2
}

\begin{abstract}
This paper discusses methods for modeling and optimizing photovoltaic and wind power plants for the integrated use of solar and wind energy. The results of modeling the dependence of the characteristics of the solar battery and wind power plants on the input parameters are presented. Changes in the output volt-ampere and power parameters depending on environmental conditions are considered. Various programming methods for mathematical modeling of power plants are presented. Methods for optimizing the output characteristics of solar cells by connecting shunt diodes are presented. The operation of solar panels is analyzed on the basis of mathematical modeling of processes. The influence of weather conditions, temperature, and light on the output parameters of solar installations was studied. The advantages of integrated use of solar and wind installations with an energy storage system are also considered. We consider the prediction of wind speeds based on various distribution functions.
\end{abstract}

\section{Introduction}

The growing interest in energy resources is linked to global warming and the effects of the greenhouse effect. Today, people understand that the reserves of fossil fuels are limited and their use leads to environmental pollution. The use of renewable energy sources (RES), which include solar radiation, wind energy, river energy, tides and ocean waves, as well as energy contained in biomass and organic waste, is becoming more attractive. Solar radiation and wind power can generate energy on a large scale [1-5]. The main disadvantages of these sources are variable characteristics and dependence on weather and climate changes. Solar and wind power alone are not able to respond to the continuous energy consumption. Combining two sources into one installation with the goal: "use the advantages of one source to overcome the weaknesses of the other." will provide economic benefits and cover the consumer's load. A photovoltaic installation that combines solar and wind power units with a battery pack can cover their individual fluctuations and reduce energy storage requirements. But the use of two different resources in combination makes the system analysis more complicated. For efficient and economical use of renewable energy sources, it is important to model each component of the system: photovoltaic modules and wind stations [5-8].

\section{Materials and methods}

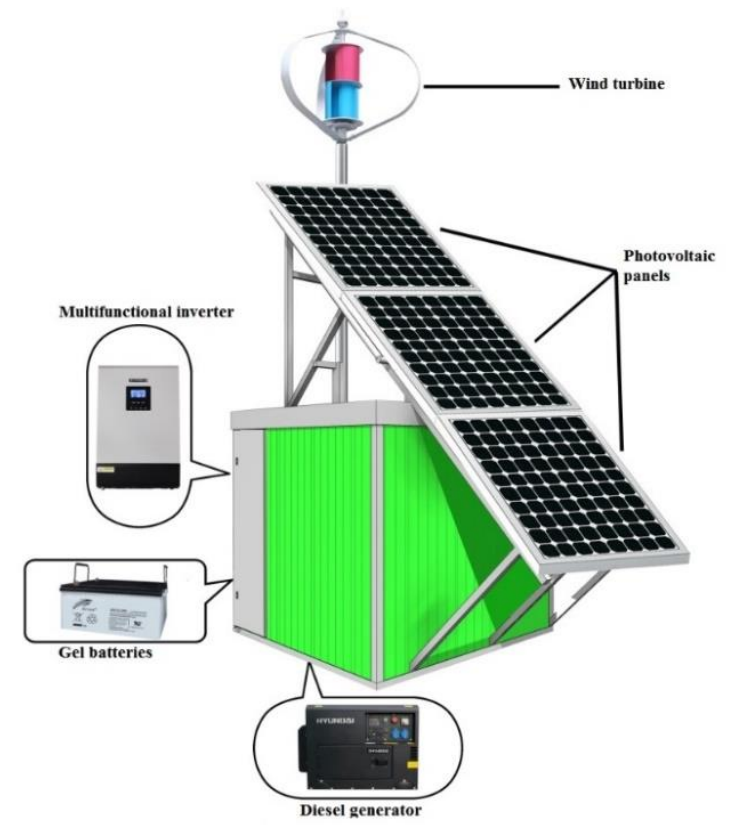

Fig. 1. General view of the wind and photo power plant [9].

A photo power plant (Fig. 1) consists of solar modules, wind turbines, batteries, an inverter, a controller, and other devices. When energy sources (solar and wind power) are plentiful, the generated power, after meeting the load demand, will charge the battery. Table 1 shows a list of the main equipment [10].

\footnotetext{
* Corresponding author: elyor.saitov@mail.uz
} 
Table 1. Shows a list of the main equipment.

\begin{tabular}{|c|c|c|c|c|}
\hline № & Appearance & Name & Description & $\begin{array}{l}\text { Quantit } \\
\text { y }\end{array}$ \\
\hline 1. & & Wind generator & $\begin{array}{l}1000 \mathrm{~W} / 24 \mathrm{~V} . \\
\quad 3 \text { the } \\
\text { blades are of } \\
\text { aluminum } \\
\text { alloy } \\
2200 / \varnothing 2400 \\
\mathrm{~mm} ., 180 \mathrm{~kg}\end{array}$ & 1 \\
\hline 2. & & $\begin{array}{l}\text { Multifunctional } \\
\text { inverter with } \\
\text { charge } \\
\text { controller }\end{array}$ & $\begin{array}{l}5 \mathrm{~kW}, 230 \mathrm{~V}, \\
\text { controller } \\
3 \mathrm{~kW}\end{array}$ & 1 \\
\hline 3. & & $\begin{array}{l}\text { Monocrystallin } \\
\text { e photo panel }\end{array}$ & $\begin{array}{l}260 \mathrm{~W} / 38 \mathrm{~V}, \\
60 \text { cells, } 21 \\
\mathrm{~kg} .\end{array}$ & 12 \\
\hline 4. & & Helium battery & 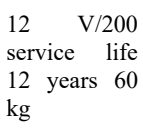 & 12 \\
\hline 5. & & $\mathrm{AB}$ rack & for $12 \mathrm{AB}$ & 1 \\
\hline 6. & & $\begin{array}{l}\text { The active } \\
\text { balancing } \\
\text { system AB }\end{array}$ & - & 3 \\
\hline 7. & & $\begin{array}{l}\text { Mounting kit } \\
\text { for PVM }\end{array}$ & $\begin{array}{l}\text { For SB 250- } \\
300 \mathrm{~W}\end{array}$ & 4 \\
\hline
\end{tabular}

Conversely, when the power sources are poor, the batteries will discharge energy to meet the load requirements. In order to predict the system's earning capacity, individual components must be modeled and then can be estimated according to the demand load [11$15]$.

\subsection{Methods of modeling solar battery}

The generalized solar cell(SC) model is shown in Fig. 2. the current source $I_{p h}$ is a photocurrent that depends on the radiation intensity, the diode VD1 describes the current flowing through a non-ideal (with a non-ideal coefficient n) p-n junction of the SC. The model includes parasitic parameters of the solar cell structure - serial resistance $R_{s}$ and parallel resistance $R_{\text {sh }}$.

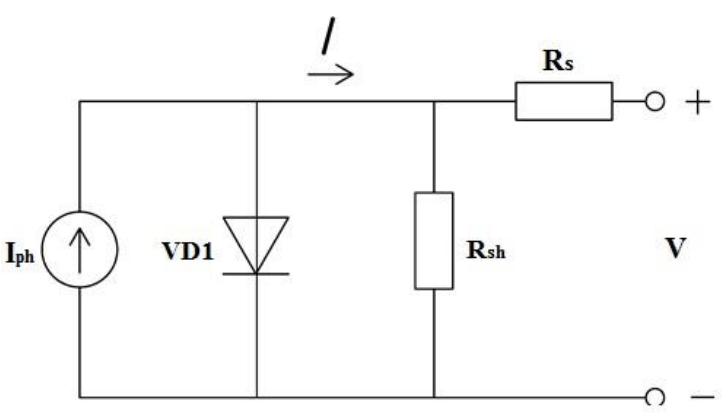

Fig. 2. Generalized scheme of SC(solar cell) substitution.

Various variants of the analytical model of the photocell are used to simulate the solar cell(SC) and solar battery(SB). A generalized SC model and several simplified versions of the model are implemented, and the simulation results are analyzed. It is shown that for photovoltaic applications, the shunt resistance of solar cells is considered large enough, and recombination in the region of the volume charge is negligible [16].

The simulation of the temperature characteristics of the solar system based on the built-in PSpice model of the diode is presented. This method of simulating temperature effects does not take into account changes in the photocurrent at different temperatures. Simulations of SC for various levels of ionizing cosmic radiation are performed [17].

The SB model is presented and various cases of battery shading are described. The positive role of shunt diodes in SB is shown: they protect the battery operation when one of the elements is completely shaded, but reduce the output voltage of the system (Fig. 3), analysis of power loss and degradation of the SB VAC during shading is quite a difficult task. Modeling the effect of arbitrary shadows on the SB characteristics makes it possible to estimate power losses for various shading options [18-20]. 


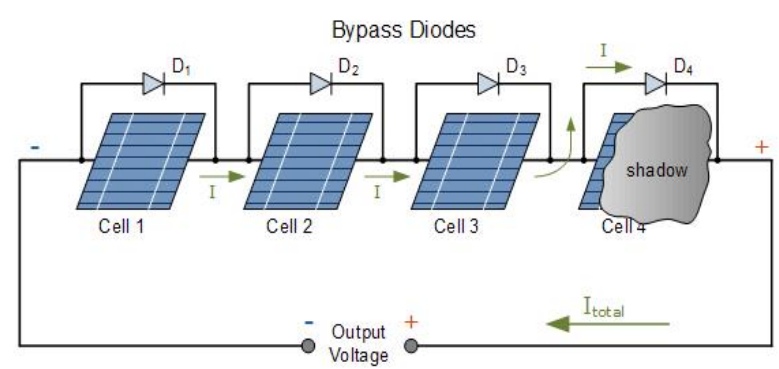

a)
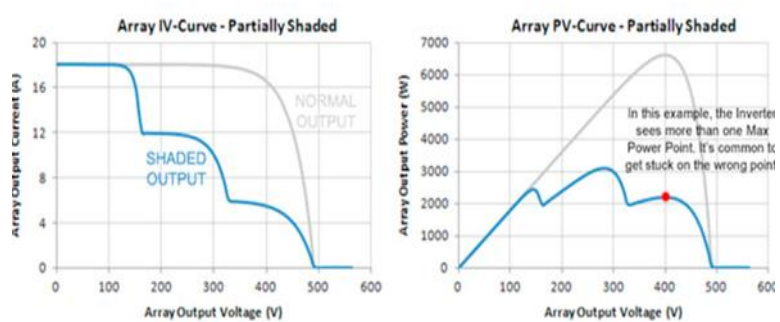

b)

Fig. 3. Modeling of solar battery shading [21] : a)-SB of 18 SC with shaded photocells and shunt diodes; b)-comparison of the VAC of a partially shaded and non-shaded battery.

The convenience of using the PSpice language consists in the simplicity of describing the cases of shading of SB and shunt diodes in the battery design. The disadvantages of such a simulation language are bulkiness, the need to adjust the source files to set different environmental conditions, and the need to first describe the library and then the schematic components. This method of modeling does not allow you to easily switch from a single SC to an arbitrary SB configuration. To build a generalized SB model, you need to use a different simulation environment [22].

Description of the solar cell model and a universal model of solar cells in the Matlab Simulink environment using the principles of visual programming [23-26].

Solar panels are a series-parallel combination of solar cells. The dependences of the SC photocurrent and the reverse saturation current on temperature and illumination are given, which are calculated using information from manufacturers.

The current-voltage characteristic of the SC is described by the formula:

$$
I_{M}=I_{p h}-I_{S}\left(e^{\frac{q}{n k T}(V+I R s)}-1\right)
$$

where, $I_{p h}-$ photocurrent; $I_{s}-$ reverse saturation current; k - Boltzmann constant; $\mathrm{T}-$ operating temperature; $\mathrm{q}$ - electron charge.

For the analytical description of the SB, the dependences of the photocurrent and the reverse saturation current of the SC on temperature and illumination are valid [27-30].
Dependence of the $\mathrm{I}_{\mathrm{ph}}$ of the $\mathrm{SC}$ on temperature and lighting

$$
I_{p h=}\left[I_{s+} K_{i}(T-298)\right] \frac{\beta}{1000}
$$

Where, $\mathrm{K}_{\mathrm{i}}=0,0017 \mathrm{~A} / \mathrm{C}, \beta$-lighting, $\mathrm{T}$ - temperature.

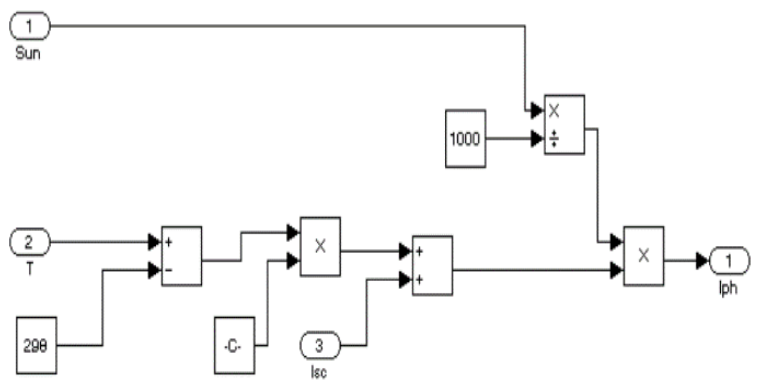

Fig. 4. $\mathrm{I}_{\mathrm{ph}}$ Photocurrent in MatlabSimulink environment depending on temperature and lighting.

The series resistance $R_{s}$ and the reverse saturation current $\mathrm{I}_{\mathrm{S}}$ depend on the manufacturing technology of the SC and strongly affect its characteristics (Fig.5, 6): with increasing $\mathrm{R}_{\mathrm{s}}$ and Is, the fill factor FF and the maximum power $\mathrm{P}_{\max }$ decrease [31-35].

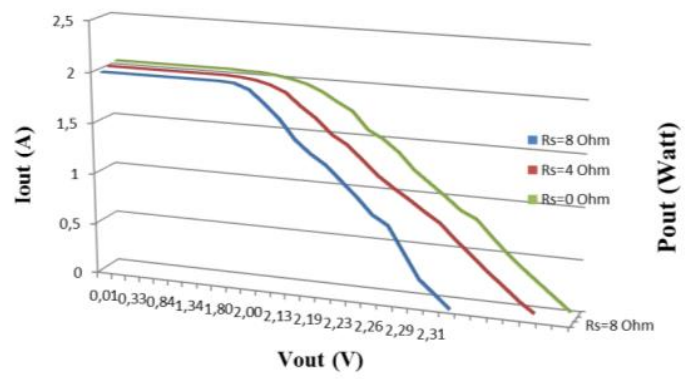

a)

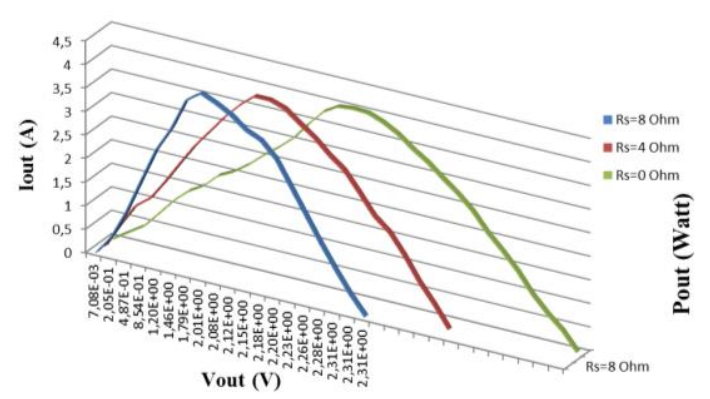

b)

Fig. 5. VAC and VVC of SC at different values of Rs : a) VAC of SC, b) VVC of SC. 


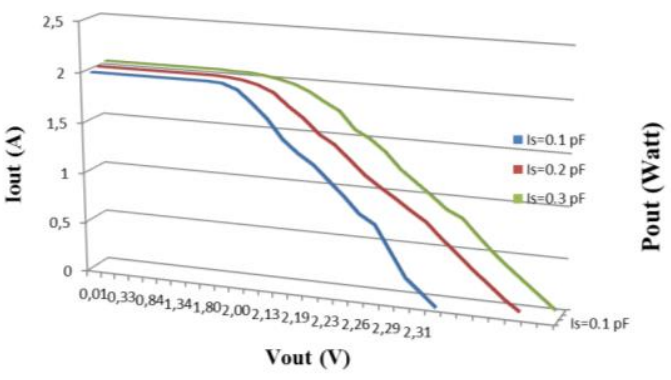

a)

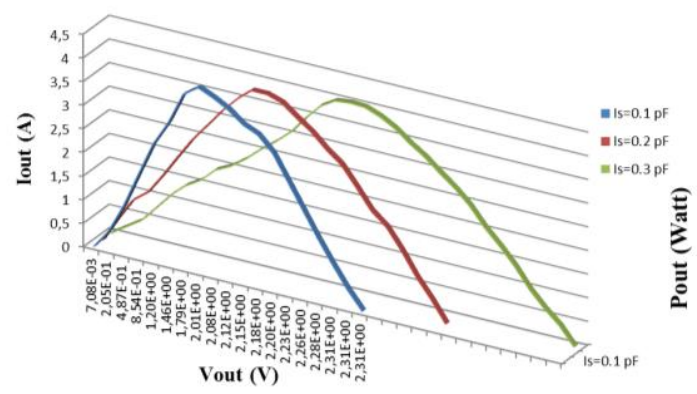

b)

Fig. 6. VAC and VVC of SC at different values Is: a) VAC of $\mathrm{SC}, \mathrm{b}) \mathrm{VVC}$ of SC.

The effect of illumination on the output characteristics of the CHN140-36P(140W) module based on single-crystal silicon solar cells is shown in Fig. 7. the results of modeling the VAC and VVC of the CHN14036P 140W module made of monocrystalline silicon with a thin film of amorphous silicon under the influence of various temperatures are shown in Fig. 8.

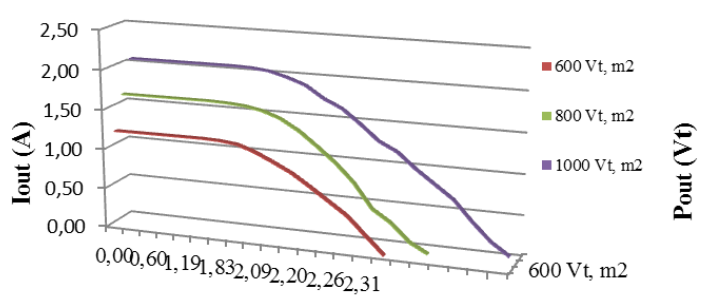

Vout (V)

a)

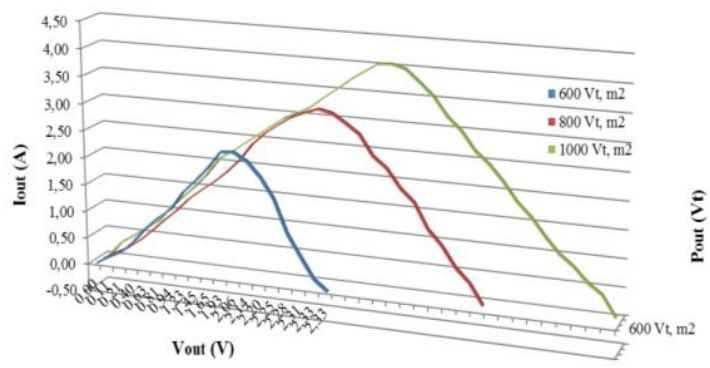

b)

Fig. 7. VAC and VVC of the CHN140-36P (140W) module under the influence of different light levels: a) VAC of the CHN140-36P , b) VVC of the CHN140-36P. 


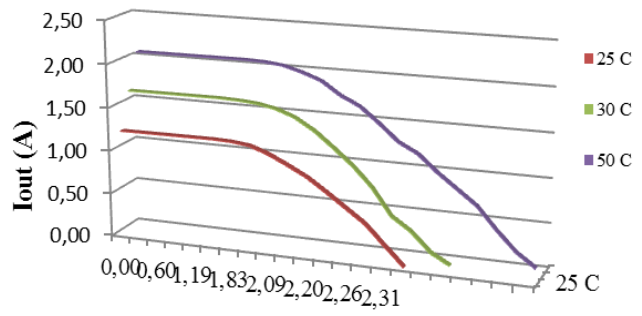

Vout (V)

a)

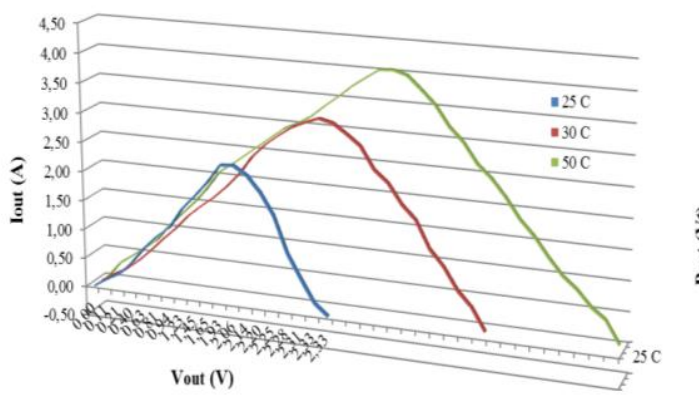

b)

Fig. 8. Modeling the effect of different temperatures on the output characteristics of the CHN140-36P(140W) module): a) VAC of SC, b) VVC of SC.

We assume that a solar cell consists of $\mathrm{N}_{\mathrm{s}}$ seriesconnected and $\mathrm{N}_{\mathrm{p}}$ parallel-connected solar cells.

Short-circuit current of the battery $I_{s c M}=N_{p} I_{s c}$, noload voltage SB $V_{o c M}=N_{S} V_{o c}$, series resistance $R_{S M}=$ $\frac{N_{S}}{N_{p}} R_{S}$.

A mathematical model describes a real object only with a certain degree of approximation. During the simulation, testing and verification of the results of SB simulation was performed. Changes in the output characteristics and design parameters of solar cells and batteries are consistent with known theoretical and practical results. The expected accuracy of the SB mathematical model is estimated at $10 \%$, taking into account the error of input data and the error of mathematical calculations. To accurately determine the model error, additional experiments and work with the database of measured VAC and VVC are required [36].

\subsection{Methods of modeling wind power plant}

The electric power of the wind power plant generator is determined by the formula:

$$
P_{v}=C_{p} \frac{\rho S}{2} V^{3}
$$

where, $\mathrm{P}_{\mathrm{v}}-$ power of wind turbines $(\mathrm{W}), \mathrm{C}_{\mathrm{p}}$ - plant efficiency, $\mathrm{S}$ - cross sectional area $\left(\mathrm{m}^{2}\right), \mathrm{V}$ - wind speed $(\mathrm{m} / \mathrm{s}), \rho$ - density $\left(\mathrm{kg} / \mathrm{m}^{3}\right)$.
Since $\rho$ and $\mathrm{S}$ are constants, the change in the power of the wind turbine will depend on the change in $C_{p}$ and $\mathrm{V}$.

To optimize the efficiency of the installation, use the formula:

$$
C_{p}(a, b)=C_{1}\left(\frac{C_{2}}{a_{i}}-C_{3} b-C_{4}\right) e^{-\frac{C_{S}}{a_{i}}}+C_{6} a
$$

where, a- the speed of the top of the rotor corresponds to the wind speed, $b$ - the normal angle of inclination from the wind direction (deg.),

$$
\begin{gathered}
\frac{1}{a_{i}}=\frac{1}{a+0,08 b}-\frac{0,035}{b^{3}+1} \\
C_{1}=0,5176 ; C_{2}=116 ; C_{3}=0,4 ; C_{4}=5 ; \\
C_{5}=21 ; C_{6}=0,0068
\end{gathered}
$$

Figure 9 shows that $C_{p}$ reaches a maximum value of 0.48 at $a=8.1$ and $b=0$.

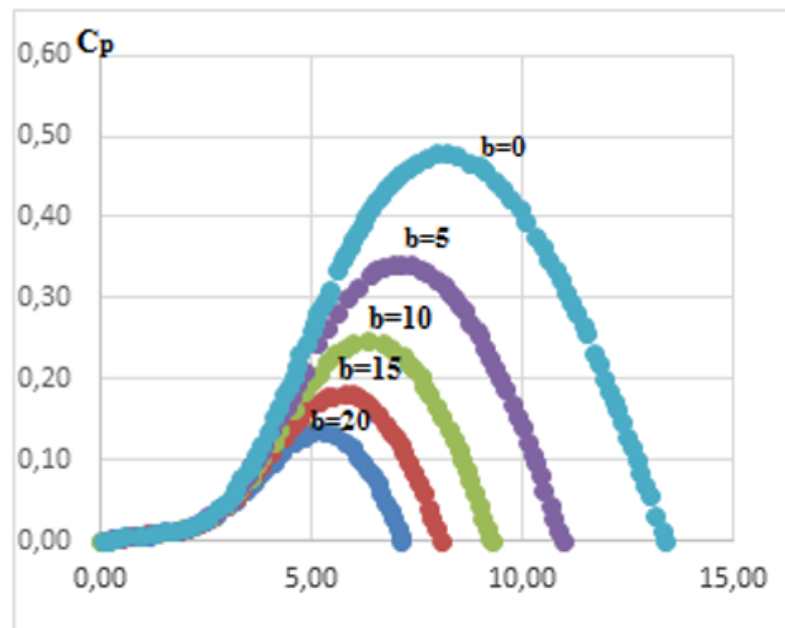

Fig. 9. Dependency $C_{p}(a, b)$.

There are various types of distribution functions of wind speeds, the Weibull, the Rayleigh, Grasevich etc. One of the most common functions in practice, which gives the most accurate results in the range of wind speeds of $4-20 \mathrm{~m} / \mathrm{s}$, is the Weibull distribution, described by the expressions:

$$
\varphi_{v}(V)=\frac{k}{A}\left(\frac{V}{A}\right)^{k-1} \exp \left[-\left(\frac{V}{A}\right)^{k}\right]
$$

Where, A - scale coefficient; $\mathrm{k}$ - the shape coefficient that characterizes the steepness of the distribution.

The graphical probability distribution function has the form shown in figure 10. the Weibull distribution Function for $\mathrm{k}=1$ corresponds to an exponential distribution and is mainly used in reliability theory. For $\mathrm{k}=3$, the Weibull distribution approximates the normal law, which is often called the parabolic law of the Gauss distribution $[37,38]$. 


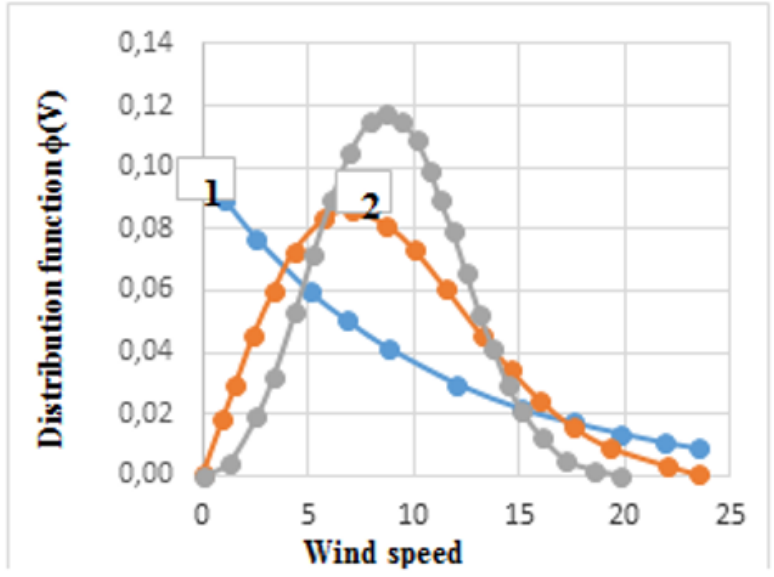

Fig. 10. Weibull probability distribution function for $A=10$ and $\mathrm{k}=1,2,3)$.

Knowing $\varphi_{v}(V)$, it is easy to calculate the average speed:

$$
V=\int_{0}^{\infty} V \varphi_{V}(V) d V=A G\left(1+\frac{1}{k}\right)
$$

Where, $\mathrm{G}$ - gamma function. The constant $\mathrm{k}$ (form parameter) usually lies in the range $1 \leq \mathrm{k} \leq 2$, and since $G(2)=1, G(1,5)=\frac{\sqrt{\pi}}{2}$ the formula (8) takes the form:

$$
V \approx(1.0 \div 0.9) A
$$

in other words, parameter A of the Weibull distribution is close to the average speed. Dependence for the accumulated probability (the probability that the speed is in the range from 0 to $\mathrm{V}$ ):

$$
F(V)=\int_{0}^{V} \varphi_{V}(V) d V=1-\exp \left[-\left(\frac{V}{A}\right)^{k}\right]
$$

The use of the Weibull distribution for predicting wind flow velocity is recommended in both foreign and domestic literature $[39,40]$.

\section{Conclusions}

The Autonomous measuring complex includes a device for recording total solar radiation, a device for recording wind characteristics, as well as units for Autonomous power supply, monitoring and storage of the received data. To register solar radiation, a thermoelectric pyranometer was selected that measures the total flux of solar radiation coming from the entire upper hemisphere. The sensor is placed under a transparent glass or plastic cover to protect it from precipitation, dust, and wind. An additional solar radiation sensor is a photovoltaic battery, which is used in the Autonomous power supply unit. A typical anemometer and wind direction meter are used to measure wind characteristics. Additionally, the ambient temperature is measured [20-27].

In the process of modeling photovoltaic and wind power modules, the dependences of the output characteristics of the SB on changes in temperature, lighting, etc. were observed. As the temperature and illumination increase, the FF fill factor and the maximum power of the Pmax decrease. The efficiency of a wind power plant reaches its maximum value at $\mathrm{a}=$ 8,1 and $\mathrm{b}=0^{\circ}$.

In Uzbekistan, solar and wind resources are monitored using automatic measurement systems. Longterm averaged weather data allows you to determine the optimal installation locations and types of solar and wind power plants that work effectively with such resources.

We would like to thank Nguyen Minh Duc, a research associate at Tomsk Polytechnic University in Russia, and Professor A.V. Yurchenko, doctor of technical Sciences, for their help in writing this article.

\section{References}

[1] Finlay Colville, Prod.\&insp.Prod.Tech., USA, 7477 (2009)

[2] Chen Jiaheand, et al., (RRL)-5 8, 277-279 (2011)

[3] I. Sapaev, E. Saitov, N. Zoxidov, B. Kamanov, IOP Conference Series: Materials Science and Engineering 883, 1, 012116 (2020)

[4] J. Toshov, E.B. Saitov, E3S Web of Conferences RSES 139, 01087, 1-4 (2019)

[5] M.K. Bakhadyrkhanov, S.A. Valiev, N.F. Zikrillaev, S.V. Koveshnikov, E.B. Saitov, S.A. Tachilin, Applied solar energy 52, 4, 278-281 (2016)

[6] Sh.A. Faiziev, Yu.B. Sobirov, Applied Solar Energy 53, 1, 57-60 (2017)

[7] Electronic resource Available at: https://kun.uz

[8] Shavkat Fayziev, Yuldash Sobirov, Sirojiddin Makhmudov, I. Jof Sand GE 7, 4, 21-28 (2018)

[9] V.S. Krivtsov, A.M. Oleynikov, et al., Textbook (Inst. Sevast., Sevast. NATs. tehn. Univ., 2003) 400

[10] Elyor Saitov, IJARSET 3, 5 (May 2016)

[11] V.S. Krivtsov, A.M. Oleynikov, et al., Inexhaustible energy (KN.2. Univ., 2004) 519

[12] V.G. Derzky, Power engineering and electrification 1, 53-56 (2010)

[13] U.A. Tadzhiev, E.I. Kiseleva, M.U. Tadzhiev, R.A. Zahidov, Part I, Solar Energy Equipment 3, 46-52 (2014)

[14] R.A. Community, V.M. Kremkow, Solar technology 4, 106-107 (2015)

[15] M.V. Zavarina (L.: Hydrometeoizdat, 1971) 162

[16] E.B. Saitov, JMSChE 4, 30-35 (2016)

[17] S.Q. Shoguchkarov, T.R. Jamolov, N.Y. Mukhtarov, I.A. Yuldoshev, Applied Solar Energy 54, 392-394 (2018)

[18] M.K. Bakhadyrkhanov, S.A. Valiev, N.F. Zikrillaev, S.V. Koveshnikov, E.B. Saitov, S.A. Tachilin, Geliotekhnika 4, 28-32 (2016)

[19] I. Sapaev, E.B. Saitov, N. Zoxidov, B. Kamanov, Conmechydro - 2020 IOP Conf. Series: Mat. Sci. Eng. 883, 012116 (2020) 
[20] E.B. Saitov, J.B. Toshov, Sh.B. Umarov, B.H. Fayzullayev, I.A. Abdullabekov, B.A. Nasriddinov, JCR 7, 15, (2020) ISSN 23945125

[21] E.B. Saitov, A.O. Pulatov, JCR 7, 15 (2020) ISSN 2394-5125

[22] N. Zikrillayev, E. Saitov, Monograph (LAP LAMBERT Academic Publishing, 2019) ISBN 987-620-0-50311-4

[23] N. Zikrillayev, E. Saitov, Sbor. Mat. Mej. Nau. ret. Onl. Konf., 53-60 (28 May 2020)

[24] E. Saitov, J. Toshov, S. Umarov, B. Nasriddinov. Sbor. Mat. Mej. Nau. - ret. Onl. Konf., 329-339 (28 May 2020)

[25] N.F. Zikrillayev, E.B. Saitov, Vestnik TashGTU 1, 51-56 (2018)

[26] B.A. Abdurakhmanov, M.K. Bakhadirkhanov, H.M. Iliyev, E.B. Saitov, et al., Nanoscience and Nanotechnology 4, 3, 41-43 (2014)

[27] B.A. Abdurakhmanov, M.K. Bakhadirkhanov, E.B. Saitov, et al., Nanoscience and Nanotechnology 4, 2, 23-26 (2014)

[28] X.M. Iliyev, E.B. Saitov, S.X. Saydaliyev, S.A. Tachilin, Prob. ener- i res. TashGTU, 1-2, 183-185 (2014)

[29] I.A. Yuldoshev, S.K. Shoguchkarov, A.R. Kudratov, T.R. Jamolov, Applied Solar Energy (English translation of Geliotekhnika) 56, 2, 125-130 (2020)

[30] S.Q. Shoguchkarov, T.R. Jamolov, N.Y. Mukhtarov, I.A. Yuldoshev, Applied Solar Energy (English translation of Geliotekhnika) 54, 5, 392-394 (2018)

[31] M.N. Tursunov, V.G. Dyskin, I.A. Yuldashev, K. Sobirov, P.J. Hwoan, Applied Solar Energy (English translation of Geliotekhnika) 51, 2, 163164 (2015)

[32] M.N. Tursunov, V.G. Dyskin, B.M. Turdiev, I.A. Yuldashev, Applied Solar Energy (English translation of Geliotekhnika) 50, 4, 236-237 (2014)

[33] M.N. Tursunov, K. Sabirov, P.J. Hwoan, A.R. Shirmatov, I.A. Yuldoshev, Applied Solar Energy (English translation of Geliotekhnika) 49, 4, 232-234 (2013)

[34] M.N. Tursunov, R.A. Muminov, V.G. Dyskin, I.A. Yuldoshev, Applied Solar Energy (English translation of Geliotekhnika) 49, 1, 16-18 (2013)

[35] M.N. Tursunov, R.A. Muminov, O.F. Tukfatullin, I.A. Yuldoshev, E.T. Abdullaev, Applied Solar Energy (English translation of Geliotekhnika) 47, 1, 63-65 (2011)

[36] T.T. Riskiev, M.N. Tursunov, S. Dadamukhamedov, I.A. Yuldoshev, M.S. Yakubova, Applied Solar Energy (English translation of Geliotekhnika) 46, 4, 248-250 (2010)
[37] I. Sapaev, E. Saitov, N. Zoxidov, B. Kamanov, IOP Conference Series: Materials Science and Engineering 883, 1, 012116 (2020)

[38] J. Toshov, E. Saitov, E3S Web of Conferences 139, 01087 (2019)

[39] T.T. Riskiev, M.N. Tursunov, S. Dadamukhamedov, O.F. Tukfatullin, Yuldoshev, I.A. Applied Solar Energy (English translation of Geliotekhnika) 46, 3, 179-181 (2010)

[40] M.K. Bakhadyrkhanov, S.A. Valiev, N.F. Zikrillaev, E.B. Saitov, S.A. Tachilin, Applied Solar Energy (English translation of Geliotekhnika) 52, 4, 278-281 (2016)

[41] N. Ketoeva, N. Soldatova, and S. Ilyashenko, Lean Manufacturing as a Tool for Increasing Labor Productivity at the Enterprise, E3S Web of conferences 124, $04015 \quad$ (2019) doi:10.1051/e3sconf/201912404015 